Check for updates

New York, USA

Cite this as: BMJ 2020;370:m2676 http://dx.doi.org/10.1136/bmj.m2676 Published: 03 July 2020

\section{Covid-19: US sees record rise in cases}

\author{
Janice Hopkins Tanne
}

On 30 June Anthony Fauci, director of the National Institute of Allergy and Infectious Diseases, told the Senate health committee that he wouldn't be surprised if the US saw 100 ooo new cases a day unless the nation got the virus under control.

On 1 July there were 52789 new cases, the largest daily increase since the pandemic began. On 2 July there were at least another 53 ooo cases, according to the Washington Post database. ${ }^{1}$ As of 2 July, the US had recorded 2739320 cases and 128743 deaths, by far the highest rates in the world. ${ }^{2}$

Cases were increasing rapidly in southern and western states, most of which had reopened their economies early and had not required mask wearing. Florida reported more than 10 ooo new cases on 2 July. On 1 July, Texas reported 8123 new cases, California 761ll, Arizona 4753, Georgia 2309, and South Carolina $1520 .^{3}$ These outbreaks account for about half of the nation's new infections.

Around half the new cases were reported in people under 35, and cases were trending upward in 38 states on 1 July. Hospitals were preparing for an increase in admissions.

Fauci said that the nation needed to act quickly to control the infection's spread because the new outbreaks put the entire country at risk. Later, in an interview with the Journal of the American Medical Association, he said that the recently reported mutation of coronavirus published in $\mathrm{Cell}^{4}$ might make the virus more infectious. ${ }^{5}$

Searching for coronavirus tests at drive through or walk in centres, residents lined up for hours in the heat. A striking photo from Austin, Texas, showed lines of cars snaking through a parking lot in a temperature of $35^{\circ} \mathrm{C}$. Temperatures throughout the region were high, ranging from $28^{\circ} \mathrm{C}$ in Miami, Florida, to $39^{\circ} \mathrm{C}$ in Phoenix, Arizona.

Testing availability varies by state, and even by location within a state. The increase in testing does not, however, explain the rise in cases, as President Donald Trump had suggested. Brett Giroir, assistant secretary of health, told a Congressional committee on 2 July, "There is no question that the more testing you get the more infections you will uncover, but we do believe this is a real increase in cases."

The increase, particularly among younger people, is thought to be related to their socialising indoors in bars, which have reopened in many states. Fauci asked states to close indoor bars, where he called crowds "bad news." Even large groups in the open air, such as the Black Lives Matter protests, are thought to be less risky.

Governors responded to the surge in cases and to the three day 4 July holiday this weekend when many people will get together for parties and barbecues. They began cutting back on reopening measures and reinstituting restrictions. Governor Greg Abbott of Texas mandated that people in most of the state must wear masks in public, cannot gather in groups larger than 10, and must stay $2 \mathrm{~m}$ apart. Governor Doug Ducey of Arizona closed bars, gyms, movie theatres, and water parks. California governor Gavin Newsom ordered businesses with indoor operations-such as bars, restaurants, and theatres-to close in the 19 largest of the state's 58 counties. Governor Ron DeSantis of Florida ordered bars and some beaches to close but has not required people to wear masks in public.

President Trump, who has resisted wearing a mask, made a U turn on 1 July and said he would have "no problem" wearing a mask at events where social distancing was not possible. The apparent turnabout was surprising, because mask wearing has become political, suggesting that the wearer is anti-Trump, while not wearing a mask suggests the wear is a Trump supporter.

Trump told Fox Business that he was "all for masks" and thought they were good, although he thought the virus would eventually disappear. ${ }^{6}$

Fox J, Mayes R, Schaul K, Shapiro L, Berkowitz B. At least 126000 people have died from coronavirus in the US. www.washingtonpost.com/graphics/2020/national/coronavirus-us-cases-deaths/?itid=Ik_inline_manual_3\&itid=Ik_inline_manual_3

2 Covid-19 dashboard by the Center for Systems Science and Engineering at Johns Hopkins University. https://gisanddata.maps.arcgis.com/apps/opsdashboard/index.html\#/bda7594740fd40299423467b48e9ecf6.

Coronavirus: Tracking the global outbreak. New York Times. 2020. www.nytimes.com/interactive/2020/world/coronavirus-maps.html.

Korber B, Fischer W, Gnanakaran W, et al. Tracking changes in SARS-CoV-2 spike: evidence that D614G increases infectivity of the covid-19 virus. Cell. 2020. www.cell.com/cell/pdf/S0092-8674(20)30820-5.pdf.

5 Conversations with Dr Bauchner. Coronavirus update with Anthony S Fauci, MD. 2 July 2020. www.youtube.com/watch?v=m515UGS9ngc.

6 Best P. Trump "all for masks," looked like "Lone Ranger” in one. 1 July 2020. www.FoxBusiness.com/lifestyle/trump-all-for-masks-looked-like-lone-ranger-inone. 